УДК 37.013:17

\title{
ПРОБЛЕМИ ЯКОСТІ ПРОФЕСІЙНОЇ ОСВІТИ В УМОВАХ ГЛОБАЛІЗАЦІЇ І ТРАНСФОРМАЦІЇ УКРАЇНСЬКОГО СУСПІЛЬСТВА
}

\author{
Ірина Грабовська, \\ кандидат педагогічних наук, докторант \\ Інституту професійно-технічної освіти НАПН Украӥни
}

\section{КЛЮЧОВІ СЛОВА: \\ професійна освіта, зміст професійної освіти, якість освіти, чинники якості професійної освіти, крос-культурний компонент, культурний потенціал держави, моніторинг професійної освіти, конкурентоспроможність фахівця}

\begin{abstract}
Реферат
У статті проведено аналіз досліджень вітчизняних та зарубіжних науковців із проблеми забезпечення якості професійної освіти в умовах глобалізації та трансформації українського суспільства, описано стан дисонансу між професійною підготовкою майбутніх фахівців та вимогами ринку праці, уточнено сутність поняття «якість професійної освіти» в динаміці його змін, підкреслюється місце та роль крос-культурного компоненту в системі професійної освіти для вирішення проблеми міжкультурної взаємодії та міжкультурних комунікацій, розкрито значний потенціал культурологічного підходу 3 метою формування фахівця високого ступеня готовності до крос-культурної взаємодії, що сприятиме професійній компетентності.

Поняття «якість освіти» визначається як сукупність соціальних норм і вимог до особистості, освітнього середовища, в якому відбувається іiі становлення та розвиток та системи освіти в цілому, 3 допомогою якої людина набуває певних знань, умінь і навичок. У статті виокремлені внутрішні та зовнішні чинники якості професійної освіти, які характеризують освітній процес та його результат, з'ясовано фактори, які забезпечують якість професійної освіти, здійснено спробу запропонувати шляхи підвищення якості професійної освіти через запровадження європейських стандартів якості професійної освіти в системі оцінювання в даній сфері та інноваційних моделей управління професійною освітою на основі врахування крос-культурного менеджменту.

Описано систему моніторингу професійної освіти, яка вибудовується на загальноприйнятих і апробованих європейських моделях порівняльної оцінки якості освіти, що враховує багатонаціональність та мультикультурність. Базуючись на загальноєвропейських та світових підходах до розбудови освітнього сектору, проблема якості професійної освіти потребує пріоритетного вирішення. Виходячи 3 цього, підкреслено важливість підвищення рівня культурного потенціалу держави, який визначається, насамперед якістю вітчизняної професійної освіти та $€$ запорукою її конкурентоспроможності та рейтингу на світовій арені.
\end{abstract}

Постановка проблеми. Геополітична спрямованість сучасного цивілізаційного процесу визначається втіленням європейських стандартів, розширенням можливостей міжкультурної взаємодії у всіх сферах життя. Ознак багатополюсності в контексті європейського вектору розвитку набуває, зокрема, галузь професійної освіти. Нині освітяни усвідомлюють себе частиною масштабного співтовариства,

необмеженого геополітичними чинниками, об'єднаного професійними інтересами, зацікавленістю щодо ефективності у розв'язанні проблеми якості освіти [6].

$$
\text { Україна, }
$$

базуючись на загальноєвропейських та світових підходах до розбудови освітнього сектору, надає важливого значення проблемі якості професійної освіти, проголошуючи іiї 


\section{Ірина Грабовська. Проблеми якості професійної освіти в умовах глобалізації і}

трансформації суспільства

національним пріоритетом та передумовою національної безпеки держави, дотримання міжнародних норм i вимог законодавства України щодо реалізації права громадян на якісну освіту, яка розглядається сьогодні не лише як інструмент соціального, культурного та економічного зростання, але й як один із чинників добробуту населення [1, с. 231-232].

Аналіз останніх досліджень та публікацій. Питаннями якості професійної освіти в умовах, що об'єктивно змінюються, займались і продовжують досліджувати відомі вітчизняні вчені: І. Зязюн, В. Курило, К. Корсак, Г. Кравченко, В. Кремень, В. Луговий, Л. Ляшенко, В. Мадзігон, Н. Ничкало, О. Овчарук, Л. Паращенко, В. Радкевич, О. Савченко, Ю. Терещенко та інші.

Метою статті $\epsilon$ аналіз проблем якості професійної освіти в контексті кроскультурного компоненту та обгрунтування сучасних підходів до підвищення якості професійної освіти.

\section{Виклад}

Інформаційне зростання рол підвищенні рівня інтелектуального та культурного потенціалу будь-якої держави. В умовах глобалізаційних викликів однією 3 найважливіших передумов економічної стабільності держави, запорукою ii конкурентоспроможності та рейтингу на світовій арені стає професійна освіта. Відповідно, зумовлюється необхідність забезпечення їі якості.

Системне дослідження якості професійної освіти передбачає вивчення комплексу проблем, які охоплюють: 3'ясування сутності базових понять якості освіти; визначення показників оцінювання якості освіти; проведення моніторингу та прийняття управлінських рішень 3 метою забезпечення встановлених норм якості професійної освіти на всіх їі рівнях; формування фахової компетентності, яка передбачає теоретичну і практичну готовність особистості до здійснення професійної діяльності.

Поняття «якість освіти» сучасною наукою визначається як сукупність соціальних норм і вимог до особистості, освітнього середовища, в якому відбувається ii становлення та розвиток, і системи освіти, за допомогою якої людина набуває певних знань і навичок [3].

Проблемам якості освіти присвячували свої трактати філософи й педагоги різних часів і народів світу. Платон, наприклад, відносив цю функцію виключно до пріоритетів держави. Аристотель однозначно пов'язував іiі зі стійкістю засвоєння знань та логікою мислення. Середньовічна філософсько-педагогічна традиція якість освіти пов'язувала 3 ефективністю засвоєння Біблії. В епоху Відродження проходить повернення піi до людини. В інтерпретації різних філософів якість освіти визначається: «освоєнням необхідної суми знань», а також «реалістичним сприйняттям набутого знання, зрозумілого самостійно» (К. Ясперс); «оптимальною організацією життєдіяльності університетів» (В. Гумбольт); здатністю «ефективно керувати технічними й соціальними системами» (Е.Тоффлер); вмінням «знайти своє місце в системі виробничих і соціальних відносин» (М. Вебер); «оволодінням загальною культурою» (М. Данилевський, П. Сорокін, А. Тойнбі) тощо.

Якість освіти є категорією, яка за своєю сутністю відображає філософські, соціальні, педагогічні, політичні, демографічні, культурні, економічні аспекти освітнього процесу. У широкому сенсі якість професійної освіти розуміють як збалансовану відповідність процесу, результату і самої освітньої системи цілям, потребам і соціальним нормам (стандартам) освіти. Якщо за основу означення взяти вимоги міжнародного стандарту якості, що регламентує поняття якості продукції i послуг, то його можна інтерпретувати як сукупність властивостей i характеристик освітнього процесу або його результату, які допомагають їм задовольняти освітні потреби всіх суб' єктів навчально-виховного процесу учнів і студентів, їхніх батьків, викладачів, роботодавців, управлінців тощо, тобто державу й суспільство загалом [8].

На сучасному етапі роль професійної освіти полягає у відтворенні соціального 
Розділ I. Теоретико-методологічні основи розвитку професійної освіти і навчання

досвіду, в трансляції і втіленні базових цінностей у розвиток українського суспільства, зростанні інтелектуального та професійного потенціалу національної економіки, врахуванні ознак полікультурності суспільства. Відтак, якість професійної освіти трактується у таких вимірах: суспільний ідеал освіченості людини; результат іiі навчальної діяльності та професійна мобільність; процес організації навчання й виховання в навчальному закладі та поза ним; критерій професійної компетентності та конкурентоспроможності в умовах майбутньої діяльності. Професійна освіта покликана готувати людину, здатну жити й ефективно діяти в умовах постійних глобалізаційних та трансформаційних процесів. Усвідомлення сутності якісної професійної освіти в умовах європейського вектору України вимагає врахування кроскультурного підходу як особливої методологічної стратегії пізнання культур 3 урахуванням їх рівноцінності, універсальності та специфічності [7]. Отож, якість професійної освіти $\epsilon$ суспільною характеристикою та показником розвитку держави. В сучасному світі вона сприймається як об'єкт поєднання різних національних освітніх систем шляхом заохочення до співпраці усіх країн, поважаючи одночасно відповідальність країнчленів $\mathrm{CC}$ за зміст навчання та організацію освітніх систем, враховуючи їхню культурну різноманітність.

Особистісно

зорієнтоване

спрямування освіти зумовлює необхідність інтегровано оцінювати якість професійної освіти в єдності індивідуальних характеристик особистості, показників організації освітнього середовища й соціальних параметрів функціонування освітніх систем. Тому доцільно вирізняти внутрішні й зовнішні чинники якості професійної освіти, які характеризують освітній процес та його результат.

Зокрема, до внутрішніх характеристик якості професійної освіти можна віднести:

a) якість освітнього процесу (науковість і доступність змісту освіти, педагогічну майстерність викладання, ефективність засобів навчання тощо); б) якість освітнього середовища (технологічність управління освітнім процесом, ефективність науково-методичної роботи, ресурсне забезпечення навчального процесу, кадровий потенціал тощо);

в) якість результатів освітнього процесу (рівень професійних умінь та навичок, широкий кругозір, ступінь соціальної адаптації та конкурентоспроможності на ринку праці, рівень компетентності) тощо.

Зовнішні показники якості професійної освіти характеризують іiі як соціальну інституцію, а саме:

а) відповідність професійної освіти європейським освітнім стандартам,

б) доступність до якісної освіти усіх громадян незалежно від їх соціального чи майнового статусу, обмежень за ознаками раси, політичних, релігійних та інших переконань, етнічного чи культурного походження;

в) наступність у можливості постійного вдосконалення та здобутті вищої кваліфікації;

г) відкриття перспектив професійного росту й соціального статусу тощо.

Основними факторами, які забезпечують якість професійної освіти є:

- навчально-методичне забезпечення навчального процесу (навчальні посібники, методичні розробки та ін.);

- застосування у навчально-виховному процесі сучасних освітніх технологій (активних методів навчання, ТЗН, Інтернеттехнологій, мультимедійе забезпечення, моделювання професійних ситуацій з метою пошуку правильних рішень та ін.),

- залучення викладачів i учнів професійних навчальних закладів до науководослідницької діяльності;

- професійна підготовка викладачів, їхні особистісні якості (порядність, відповідальність, принциповість, толерантність тощо);

- наявність системи контролю й оцінки викладання, рівня знань учнів;

- належне матеріально-технічне забезпечення навчального процесу;

- відповідність програм навчальних дисциплін сучасним вимогам; 
Ірина Грабовська. Проблеми якості професійної освіти в умовах глобалізації $\mathrm{i}$ трансформації суспільства

\begin{abstract}
- контакти 3 провідними закордонними фахівцями та можливість стажування за кордоном;

- забезпечення науковою літературою, що відповідає сучасним вимогам;

- використання матеріалів соціологічних та інших досліджень [4].

Слід визнати, що нині все ще немає єдиних стандартів якості професійної освіти, якими можна було б охопити систему оцінювання в даній сфері. Визначимо деякі з них:

- посилення роз'яснення ключового значення інтеграційного зростання інтересу до оцінювання компетентностей та результатів, що учень може продемонструвати у результаті майбутньої професійної діяльності;
\end{abstract}

- збільшення зацікавленості до проектних робіт та оцінювання їх результатів;

- підвищення рівня державних освітніх стандартів;

- запровадження незалежної, об'єктивної системи контролю.

До функцій управління якістю освіти відносять: прогнозування, програмування, планування, організацію, регулювання, контроль, аналіз, стимулювання та інші. Реалізовувати всі ці функції означає здійснювати оцінювання якості професійної освіти як процесу, результату чи системи загалом, рівень засвоєння змісту освіти, демографічні показники доступу до освіти, дані кадрового й ресурсного забезпечення, економічні та культурні індикатори освіти тощо.

Сучасний менеджмент в системі оцінювання якості професійної освіти грунтується на запровадженні діагностичних методів і технологій збирання й обробки здобутої інформації, протиставляючи їх декларативності та суб'єктивності інтерпретації одержаних даних. Це вимагає постійного обстеження, налагодження системи моніторингу освіти, головною метою якої стає збір, оцінка та аналіз іiі якісних показників на всіх рівнях функціонування, поширення й доступ до цієї інформації громадськості, усіх користувачів освітніх послуг, посилення управлінських дій щодо якісних показників в освіті.
Як зазначає В. Радкевич, децентралізація управління професійною освітою $\epsilon$ ефективною за умови готовності суб'єктів управління сприймати нові ідеї, швидко розробляти й приймати ефективні управлінські рішення за умови інформаційноаналітичного супроводу управлінської діяльності як на загальнодержавному i регіональному, так і на рівні професійного навчального закладу [5].

Дієвим інструментарієм оцінювання якості професійної освіти повинен стати моніторинг, за результатами якого органи управління отримуватимуть інформацію про стан освітньої системи, 3'ясовуватимуть тенденції розвитку освіти і прогнозуватимуть зміни, необхідні для перспективного функціонування системи професійної освіти. Система моніторингу якості професійної освіти включає акцентоване та узагальнене оцінювання якості функціонування національної системи професійної освіти та порівняння iï показників 3 міжнародними індикаторами i системами, забезпечення єдиної методології професійної підготовки, аналіз і порівняння стану реалізації державної політики в галузі професійної освіти [2].

Управління якістю освіти $\epsilon$ двовекторним процесом. 3 одного боку, воно має забезпечувати якість внутрішніх параметрів процесу й результату навчання учнів і студентів, задоволення їхніх освітніх потреб і сподівань щодо здобуття належної компетентності i життєво значущих рис особистості. 3 іншого боку, воно спрямоване на поліпшення використання ресурсів для забезпечення якості освіти та підвищення ефективності функціонування системи освіти загалом, тобто на іï зовнішні параметри як соціальної системи. У першому випадку прийняття управлінських рішень грунтується на результатах вивчення рівня засвоєння змісту освіти й чинників, які на нього впливають. Суттєвим тут стає вибір критеріїв, об'єктивність оцінювання навчальних досягнень учнів і спроможність порівнювати одержані результати.

\begin{tabular}{lrl}
\multicolumn{1}{c}{ Система моніторингу професійної } \\
освіти має & вибудовуватися на \\
загальноприйнятих і апробованих моделях \\
порівняльної оцінки якості освіти, що існують
\end{tabular} 
у світі, зокрема європейських. Будь-яка держава, що дбає про свій рейтинг цивілізованості у світі, повинна розробляти стратегію й тактику управління освітою. Виходячи 3 цього, роль управлінського рішення $\epsilon$ значущою не тільки для сьогодення, але й для перспективного розвитку професійної освіти як системного явища.

Висновок. Таким чином, на основі аналізу теоретичних джерел уточнено сутність поняття «якість професійної освіти», виокремлені внутрішні та зовнішні чинники якості професійної освіти, розкрито значний потенціал культурологічного підходу в системі професійної освіти 3 метою формування фахівця високого ступеня

\section{Література}

1. Васянович Г. П. Інформаційні технології для якісної та доступної освіти / Г. П. Васянович // Педагогічна і психологічна науки в Україні. Збірник наукових праць до 15-річчя АПН України у 5 томах. / Том 5. Неперервна професійна освіта: теорія і практика. - К. : Педагогічна думка, 2007. C. 231-240.

2. Кремень В. Г. Актуальні проблеми філософії соціального управління соціальними системами / В. Г. Кремень, С. М. Пазиніч, О.С. Пономарьов та ін. // Щоквартальний науково-практичний журнал, 2008. - №1. - C. 3-10.

3. Кремень В. Г. Якісна освіта і нові вимоги часу / В. Г. Кремень // Педагогічна i психологічна науки в Україні. Збірник наукових праць до 15-річчя АПН України у 5 томах. / Том 1. Теорія та історія педагогіки. К. : Педагогічна думка, 2007. - С. 11-23.

4. Лукіна Т. О. Моніторинг якості освіти як інформаційна основа управління освітою в Україні / Т. О. Лукіна // Педагогічна і психологічна науки в Україні. Збірник наукових праць до 15-річчя АПН України у 5 томах. / Том 2. Дидактика, методика, готовності до крос-культурної взаємодії, що сприятиме професійній компетентності та конкурентоспроможності на ринку праці. Для вирішення проблеми міжкультурної взаємодії та професійної комунікації, а також для підвищення якості професійної освіти зазначено актуальність крос-культурного компоненту.

Систему професійної освіти нині лихоманить, утворюється дисонанс між реальним станом професійної підготовки майбутніх фахівців та вимогами ринку праці, тому надважливим завданням стає впровадження інноваційних моделей управління професійною освітою на основі врахування крос-культурного менеджменту, що стане перспективою наших подальших досліджень..

інформаційні технології. - К. : Педагогічна думка, 2007. - С. 134-144.

5. Радкевич В. О. Принципи модернізації професійно-технічної освіти / В. О. Радкевич // Проблеми підготовки сучасного вчителя: зб.наук.пр. Уманського державного педагогічного ім. П.Тичини. - Умань: ПП Жовтий, 2011. - Випуск 3 - С. 331-337.

6. Семенюк Е. П. Глобалізація: світло та тіні реального розвитку людства / Е. П. Семенюк, I. І. Виноградов // Вісник Житомирського державного університету. 2003. - Вип. 12. - С. 15-18.

7. Солодка А. К. Теоретико-методичні засади крос-культурної взаємодії учасників педагогічного процесу вищих навчальних закладів: автореф. дис. на здобуття наук. ступеня доктора пед. наук : спец. 13.00.07 «теорія i методика виховання» / А. К. Солодка. - К., 2016. - 42 с.

8. Товажнянський Л. Л. Процесний підхід до управління й забезпечення гарантії якості вищої освіти / Л. Л. Товажнянський та ін. // Теорія i практика управління соціальними аспектами // Щоквартальний науковопрактичний журнал. - 2008. - № 2. - С. 57-64. 


\section{Реферат \\ Проблемы качества профессионального образования в условиях глобализации и трансформации украинского общества}

\section{КЛЮЧЕВЫЕ СЛОВА:}

профессиональное образование, содержание профессионального образования, качество образования, факторы качества профессионального образования, кросскультурный компонент, культурный потенциал государства, мониторинг профессионального образования, конкурентоспособность специалиста

\author{
Ірина Грабовська,
наук, докторант, \\ кандидат педагогических наук, докторант, \\ Института профессионально-технического образования НАПН Украины
}

\begin{abstract}
Йститута просьессионально-технического образования НАПН Украины
\end{abstract}
В статье проведен анализ исследований отечественных и зарубежных ученых по проблеме обеспечения качества профессионального образования в условиях глобализации и трансформации украинского общества, описано состояние диссонанса между профессиональной подготовкой будущих специалистов и требованиями рынка труда, проведен анализ сущности понятия «качество профессионального образования» в динамике его изменений, подчеркивается место и роль кросс-культурного компонента в системе профессионального образования для решения проблемы межкультурного взаимодействия и межкультурных коммуникаций, раскрыто значительный потенциал культурологического подхода с целью формирования специалиста высокой степени готовности к кросс-культурному взаимодействию, что способствовует профессиональной компетентности.

Понятие «качество образования» определяется как совокупность социальных норм и требований к личности, образовательной среды, в которой происходит ее становление и развитие и системы образования в целом, при помощи которой человек приобретает определенных знаний, умений и навыков. В статье выделены внутренние и внешние факторы качества профессионального образования, характеризующие образовательный процесс и его результат, выяснены факторы, которые обеспечивают качество профессионального образования, предпринята попытка предложить пути повышения качества профессионального образования через внедрение европейских стандартов качества профессионального образования в системе оценивания в данной сфере и инновационных моделей управления профессиональным образованием на основе учета кросс-культурного менеджмента.

Описана система мониторинга профессионального образования, которая строится на общепринятых и апробированных европейских моделях сравнительной оценки качества образования, учитывая многонациональность и мультикультурность современного общества. Основываясь на общеевропейских и мировых подходах к развитию образовательного сектора, проблема качества профессионального образования требует приоритетного решения. Исходя из этого, подчеркнута важность повышения уровня культурного потенциала государства, что определяется, прежде всего качеством отечественного профессионального образования и является залогом его конкурентоспособности и рейтинга на мировой арене.

\section{Abstract \\ Problems of Quality of Professional Education in Globalization and Transformation of Ukrainian Society}

Iryna Hrabovska, Ph.D., doctoral candidate at the Institute of Vocational Education of NAES of Ukraine

\section{KEY WORDS: \\ professional education, content of vocational education, quality of education,}

The article analyses research findings of domestic and foreign scientists on the problem of ensuring the quality of vocational education in the conditions of globalization and transformation of Ukrainian society, clarifies the essence of the concept of «the quality of vocational education» in the dynamics of its changes, emphasizes the place and role of the cross-cultural component in the system of vocational education for solving problems of intercultural interaction and 
factors of quality of professional education, cross-cultural component, cultural potential of the state, monitoring of vocational education competitiveness of a specialist intercultural communication.

The concept «quality of education» is determined as a cluster of social norms and requirements to personality, educational environment in which a personality develops and is formed and systems of education on the whole, with the help of that a person acquires certain knowledge, abilities and skills.

In the articles internal and external factors qualities of vocational education are distinguished, that characterize an educational process and its results. Factors that ensure the quality of professional education are found out. An attempt to propose new ways of upgrading of vocational education through the input of the European standards of vocational education quality in the evaluation system in this sphere and through an introduction of innovative models of vocational education management with regards to cross cultural management.

The system of monitoring of vocational education is described, what is built on the generally accepted and approved European models of comparative estimation of quality of education with regard to multiculturalism.

\section{References}

1. Vasyanovych H. P. Informatsiyni tekhnolohiyi dlya yakisnoyi ta dostupnoyi osvity / H. P. Vasyanovych // Pedahohichna i psykholohichna nauky $\mathrm{v}$ Ukrayini. Zbirnyk naukovykh prats do 15-richchya APN Ukrayiny u 5 tomakh. / Tom 5. Neperervna profesiyna osvita: teoriya i praktyka. - K.: Pedahohichna dumka, 2007. - S. 231-240.

2. Kremen V.H. Aktualni problemy filosofiyi sotsialnoho upravlinnya sotsialnymy systemamy / V. H. Kremen, S. M. Pazynich, O. S. Ponomarov // Shchokvartalnyy naukovopraktychnyy zhurnal. -2008 . - № 1. - S. 3-10.

3. Kremen V.H. Yakisna osvita i novi vymohy chasu / V. H. Kremen // Pedahohichna i psykholohichna nauky $\mathrm{v}$ Ukrayini. Zbirnyk naukovykh prats do 15-richchya APN Ukrayiny u 5 tomakh. / Tom 1. Teoriya ta istoriya pedahohiky. - K. : Pedahohichna dumka, 2007. S. 11-23.

4. Lukina T. O. Monitorynh yakosti osvity yak informatsiyna osnova upravlinnya osvitoyu $\mathrm{v}$ Ukrayini / T. O. Lukina // Pedahohichna i psykholohichna nauky $\mathrm{v}$ Ukrayini. Zbirnyk naukovykh prats do 15-richchya APN Ukrayiny u 5 tomakh. / Tom 2. Dydaktyka, metodyka, informatsiyni tekhnolohiyi. - K. : Pedahohichna dumka, 2007. - S. 134-144.

5. Radkevych V. O. Pryntsypy modernizatsiyi profesiyno-tekhnichnoyi osvity / V. O. Radkevych // Problemy pidhotovky suchasnoho vchytelya: zb.nauk.pr. Umanskoho derzhavnoho pedahohichnoho im. P.Tychyny. 2011. - Vyp. 3 - S. 331-337.

6. Semenyuk E. P. Hlobalizatsiya: svitlo ta tini realnoho rozvytku lyudstva / E. P. Semenyuk, I. I. Vynohradov // Visnyk Zhytomyrskoho universytetu. - 2003. -Vyp. 12. - S. 15-18.

7. Solodka A. K. Teoretyko-metodychni zasady kros-kulturnoi vzaiemodii uchasnykiv pedahohichnoho protsesu vyshchykh navchalnykh zakladiv: avtoref. dys. na zdobuttia nauk. stupenia doktora ped. nauk : spets. 13.00.07 «teoriia i metodyka vykhovannia» / A. K. Solodka. - K., 2016. -42 s.

8. Tovazhnyanskyy L. L. Protsesnyy pidkhid do upravlinnya i zabezpechennya harantiyi yakosti vyshchoyi osvity / L. L. Tovazhnyanskyy ta in. // Teoriya i praktyka upravlinnya sotsialnymy aspektamy // Shchokvartalnyy naukovo-praktychnyy zhurnal. - 2008. - № 2. - S. 57-64. 